http://jmscr.igmpublication.org/home/ ISSN (e)-2347-176x ISSN (p) 2455-0450

crossref DOI: https://dx.doi.org/10.18535/jmscr/v8i7.17

Journal Of Medical Science And Clinical Research

\title{
Clear Cell Sarcoma of the Kidney: Correlational Study
}

Authors

\section{Teena Sharma ${ }^{*}$, Hema Udawat ${ }^{2}$, Ranjana Solanki ${ }^{3}$, Deepika Hemrajani $^{4}$, Arpita Jindal ${ }^{5}$}

${ }^{1} 3^{\text {rd }}$ year Resident, Department of Pathology, SMS Medical College, Jaipur

${ }^{2}$ Associate Professor, Department of Pathology SMS medical College, Jaipur

${ }^{3}$ Senior Professor, Department of Pathology, SMS Medical College, Jaipur

${ }^{4}$ Associate Professor, Department of Pathology, SMS Medical College, Jaipur

${ }^{5}$ Senior Professor, Department of Pathology, SMS Medical College, Jaipur

*Corresponding Author

Teena Sharma

Department of Pathology, SMS Medical College, Jaipur, India

\section{Abstract}

Clear cell sarcoma of kidney is a rare malignant renal neoplasm of childhood, known for its aggressiveness, its tendency for recurrence and metastasis to bone. Three cases of clear cell sarcoma are being reported.

Case 1: A two year old male child having complaint off pain in right lumbar region.USG abdomen revealed right hypoechoic lesion. CECT abdomen revealed 13x11xlocm heterogenous mass involving right kidney. Microscopy revealed clear cell sarcoma of kidney (classic pattern). Immunohistochemistry showed strong vimentin positivity and negative for cytokeratin and WT-1.

Case 2: A thirty months old male child having complaint of pain in left abdominal region since 8 months. There was history of fever and increased micturition. There was no history of weight loss. His vitals stable. Biochemical and hematological profiles were normal. USG revealed left heterogenous mass lesion $m s$ 6x4x2cm involving left kidney. CT revealed hypoechoic heterogenous mass $m s$ $6 \times 4 \times 2 \mathrm{~cm}$ involving left kidney. Microscopy revealed clear cell sarcoma.

Case 3: A 2 year old male child presented with right abdominal pain since 1 year. There was no history of fever, weight loss, hematuria. On examination patient had pallor only. Hematological finding normal. Urine examination normal. Chest $X$-ray normal. USG revealed right hypoechoic heterogenous mass ms $13 \times 10 \times 10 \mathrm{~cm}$ involving right kidney. CT revealed hypoechoic heterogenous mass $\mathrm{ms} 13 \times 10 \times 10 \mathrm{~cm}$ involving right kidney.

The purpose of this paper is to review the published series and case reports of CCSK and to create an up-to-date overview of clinical and histological features and IHC.

Keywords: Tumor, Malignant, Bone metastasizing, child.

\section{Introduction-}

Clear cell sarcoma of kidney (CCSK) is a rare malignant neoplasm of childhood, known for its aggressiveness, its tendency for recurrence and metastasis to bone $\mathrm{e}^{1,2}$. Its peak incidence is in 3-5 years with slight male preponderance ${ }^{3}$. In this study, we report three cases of clear cell sarcoma 
kidney, which were diagnosed in Department of Pathology, SMS medical college, Jaipur.

\section{Case 1}

A two year old male child presented with complaint of pain in right lumbar region since 6 months. There was no history of hematuria, vomiting, loss of weight. On examination patient had pallor, Vitals were stable. Investigations revealed: Hemoglobin of $11 \mathrm{gm} \%$, normal total and differential cell count, ESR $15 \mathrm{~mm} / \mathrm{hr}$. Urine examination was normal.USG whole abdomen revealed a $13 \times 10 \times 10 \mathrm{~cm}$ hypoechoic heterogenous mass uniformly involving right kidney. CECT abdomen revealed $13 \times 8 \times 6 \mathrm{~cm}$ heterogenous mass involving right kidney. Provisional diagnosis of Wilms tumor was made on radiology. Right nephrectomy was done and specimen was sent for histopathological examination. On gross examination nephrectomy specimen measured $15 \times 12 \times 12 \mathrm{~cm}$. External surface grey brown bosselated, covered by Gerotas fascia with no capsular breach. On cutting tumor ms $13 \times 10 \times 10 \mathrm{~cm}$, and grey white, glistening and showed focal whorled appearance. At one end normal kidney parenchyma identified (Fig 1). Microscopically revealed presence of monomorphic cells arranged in sheets and nests separated by delicate arborizing fibro vascular network. The cells were polygonal to spindle shaped with indistinct cell borders and vesicular nucleus showing grooves at many places and variable mitosis. Diagnosis of clear cell sarcoma of kidney (classic pattern) was made (Fig 2a and 2b). Immunohisto chemistry showed strong positivity for vimentin and negativity for cytokeratin and WT-1 (Fig 3a, b, c).

\section{Case 2}

An thirty months old male child presented with complaint of pain in left abdominal region since 8 months. There was past history of fever and increased micturition. His vitals were stable. Biochemical and Hematological profiles were normal. USG revealed left heterogenous mass lesion $\mathrm{ms} 6 \times 4 \times 2 \mathrm{~cm}$ involving left kidney. CT revealed hypoechoic heterogenous mass $\mathrm{ms}$ $6 \times 4 \times 2 \mathrm{~cm}$ involving left kidney. Patient underwent surgery and specimen was sent for histopathological examination. Gross examination showed unoriented grey white soft tissue mass ms $6 \times 4 \times 2 \mathrm{~cm}$. External surface was grey white. Cut surface fleshy grey white. Microscopically showed round to oval cells having vesicular nuclei, inconspicuous nucleoli, clear to eosinophilic cytoplasm arranged diffusely and in nest, surrounded by delicate arborizing vasculature. Occasional nuclear grooving also noted. Mitosis are brisk. Feature favoured diagnosis of clear cell sarcoma kidney (Classic pattern).

\section{Case 3}

A 2 year old male child presented with right abdominal pain since 1 year. There was no history of fever, weight loss, hematuria. On examination patient had pallor only. Hematological profile was normal. Urine examination normal. Chest X-ray normal. USG revealed right hypoechoic heterogenous mass ms $13 \times 10 \times 10 \mathrm{~cm}$ involving right kidney. CT revealed hypoechoic heterogenous mass $\mathrm{ms} 13 \times 10 \times 10 \mathrm{~cm}$ involving right kidney. Right nephrectomy was done and specimen was sent for histopathological examination. On gross examination specimen measured $15 \times 12 \times 10 \mathrm{~cm}$. External surface bosselated in appearance. No breaching of capsule seen. Cut surface showed a tumor ms $13 \times 10 \times 10 \mathrm{~cm}$ and grey white, showed whorling appearance. At one end normal kidney parenchyma identified. Microscopically revealed presence of monomorphic tumor cells arranged in cords, sheets, nests and alveolar pattern separated by thin capillary network. The cells were spindle shaped to oval with distinct cell borders and vesicular nucleus showing nuclear grooves at many places and variable mitosis surrounded by compressed normal renal tissue. Overall morphology favoured diagnosis of clear cell sarcoma of kidney (Classic pattern). 


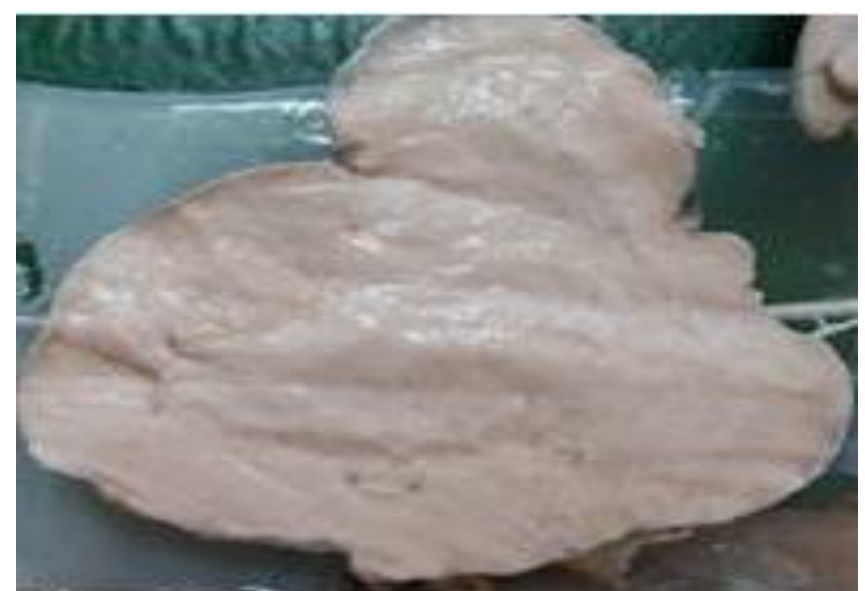

Fig 1.Right nephrectomy specimen of clear cell sarcoma kidney. Cut surface grey white, transluscent.

$2 \mathbf{a}$

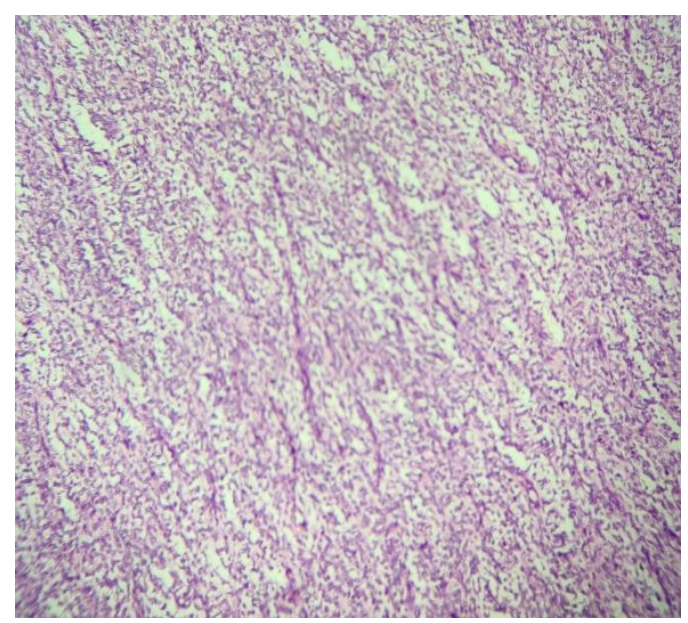

$2 b$

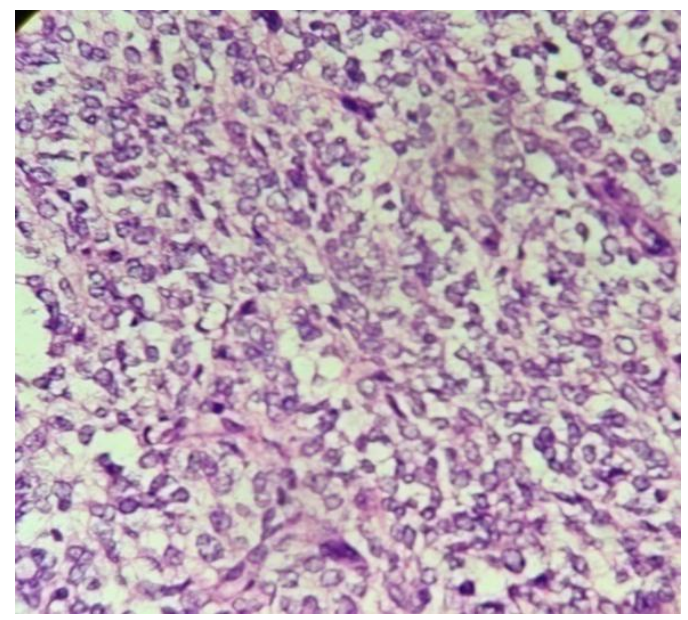

Fig 2. Microscopic view a).Tumor cells arranged in nest pattern. (10x) b). Tumor cells having vacuolated cytoplasm and surrounds by delicate vasculature.(40x) 3a

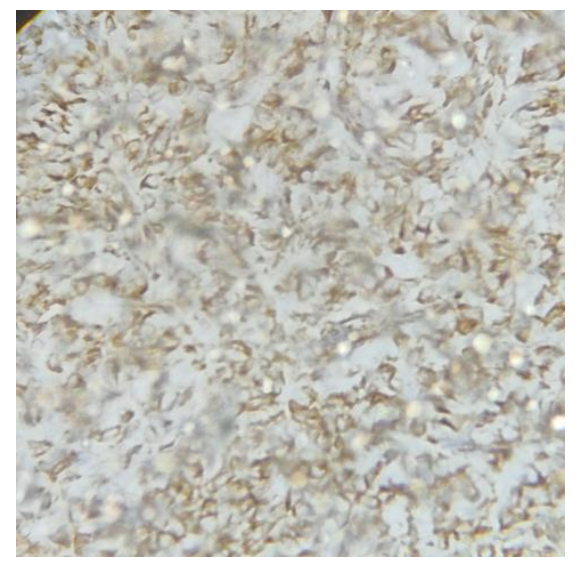

3b

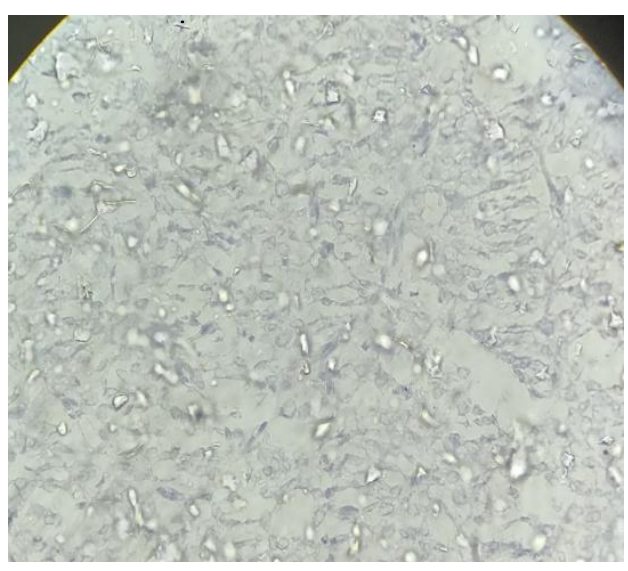

$3 c$

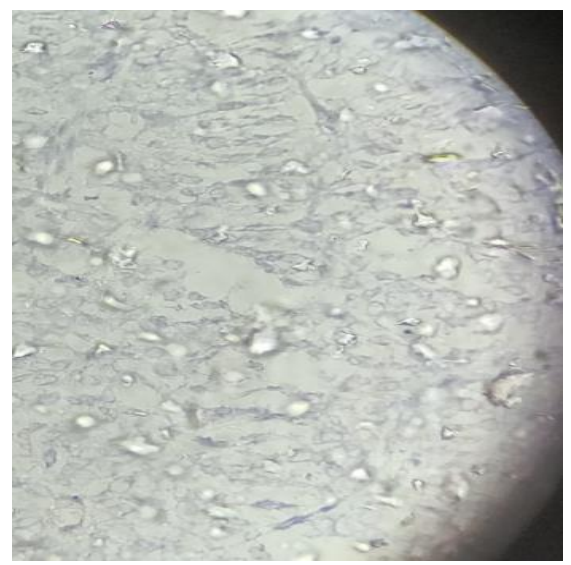

Fig 3a). Tumor cells show vimentin positivity. b). Cytokeratin negative. c) WT1 negative.

\section{Clinical Features}

The mean age of presentation in my study is about 24 months. Argani et al found that $50 \%$ of their 351 cases were diagnosed between 2 and 3 years of age $\mathrm{e}^{4-6}$. CCSK is extremely rare in the first 6 months of life and in adults. ${ }^{7-20}$ The youngest 
CCSK patient reported in literature was a foetus (at 31week gestation) and the oldest patient was 58 years old. ${ }^{8,16}$

Contrary to WT's slight propensity to the female gender, a male predominance has been noted in all large CCSK series (average male to female ratio of about $2: 1)^{4,6}$ In my study all three cases male predominace noted.

All three patients in my study series show common clinical presentation of abdominal pain. One case has fever and increased micturition also noted. Other symptoms that have been described are hematuria, vomiting, decreased oral intake, constipation and hypertension ${ }^{21-25}$ in other studies which were absent in my study series. Some study suggested a predilection for involvement of the right kidney, in my study case 2 out 3 showed right predilection.

\section{Pathology}

All CCSK typically presents as a large, unicentric, well circumscribed and sharply demarcated mass. The tumor arises from the central region and replaces normal kidney tissue or is located in the medulla of the kidney. ${ }^{26}$ The diameter of the tumor ranges in my study from 6 to $13 \mathrm{~cm}$. CCSK is soft, tan grey in color. External surface bosselated and cut surface glistened due to mucinous material in all cases.

Microscopically classic pattern predominant on other histologic patterns. In other studies also classic pattern is more common. The classic subtype of CCSK is characterized by round /oval cells with clear cytoplasm, fairly uniform round/ oval and often vesicular bland nuclei with finely dispersed chromatin, inconspicuous nucleoli and infrequent mitotic figures. ${ }^{26,27}$ In the classic pattern, tumor cells are arranged in nests or cords, separated by fibrovascular septa. ${ }^{28}$ Other pattern that have been described include myxoid, sclerosing, cellular, epitheloid, pallisading, spindle cell, storiform and anaplastic. ${ }^{29}$

The histological heterogeneity emphasizes the importance of discriminating the disease from other entities. Considering the low incidence of
CCSK from other renal tumors, it is important that suspected CCSK cases are reviewed by pathologists who were experts in paediatric renal tumors.

\section{Immunohistochemistry}

Immunohistochemistry can help to distinguish CCSK from other renal tumors of childhood. IHC done in one of the 3 cases shows non specific vimentin positivity and negativity for WT-1 and cytokeratin.

\section{Discussion and Conclusion}

Clear cell sarcoma also known as "Bone metastasizing tumor of Childhood" comprise 4\% of all primary childhood renal tumors ${ }^{30}$. Histological variants of CCSK include spindle cell, sclerosing, epithelioid, myxoid, pallisading, storiform and anaplastic clear cell sarcoma ${ }^{31}$. Accurate and early diagnosis of clear cell sarcoma as a separate entity from wilms tumor is of extreme importance. Careful study of morphology, the characteristic delicate arborizing vascular septae, monomorphous population and invasive property will help to distinguish it from more common and less aggressive counterparts of childhood renal neoplasm like Wilms tumor ${ }^{32}$. Points helpful in this matter are: Foci of blastema are not seen in clear cell sarcoma; nonrenal elements such as cartilage or muscle are not found in clear cell sarcomas. Clear cell sarcomas are unilateral and unicentric, and sclerotic stroma is uncommon in wilms tumor before therapy. The vascular pattern typical of clear cell sarcoma is often often helpful in distinguishing it from Wilms tumor. The border with the kidney is usually infiltrative in CCSK, whereas the border of Wilms tumor is typically pushing ${ }^{33}$.

Immunohistochemistry for Clear cell sarcoma which is positive for vimentin negative for WT1, and wilms tumor positive for WT 1 . Treatment of CCSK generaly involve surgical intervention coupled with radiation and chemotheraphy with cyclophosphamide, etoposide and vincristin and doxorubicin for 24 weeks It is of considerable 
therapeutic importance that CCSK be not only correctly diagnosed but early too.

\section{References}

1. Sharma SC, Menon PA.Clear cell sarcoma of the kidney. J Postgrade Med 2001; 47:206-7.

2. Namaoui RY, Castex MP, Vial J , Galinier P, Rubie H, Laprie Mazieres A, et al.Clear cell sarcoma of the kidney: About a pediatric case.Prog Urol 2010;20:465-8.

3. Argani P, Perlman EJ, Breslow NE, Browning NG, Green DM, D Angio et al.Clear cell srcoma kidney: A review of 351 cases from the National Wilms Tumor Study Group Pathology Center.Am J Surg Pathol 2000;24:4-18.

4. Seibel NL, Sierra LI, Breslow NE, Beckwith JB, Green DM. Eff ect of duration of treatment on treatment outcome for patients with clear-cell sarcoma of the kidney: a report from the National Wilms' Study Group. J Clin Oncol 2004;22:468-73.

5. Green DM, Breslow NE, Beckwith JB, Moksness J, Finklestein JZ, D'Angio GJ. Treatment of children with clear-cell sarcoma of the kidney: a report from the National Wilms' Tumor Study Group. J Clin Oncol 1994;12:2132-7.

6. Seibel N, Sun J, Andersen JR. Outcome of clear cell sarcoma of the kidney (CCSK) treated on the National Wilms' Tumor Study-5 (NWTS). 24,5022006 Ref Type Conf Proc Ref ID 2006:6076.

7. Van den Heuvel-Eibrink MM, Grundy $\mathrm{P}$, Graf $\mathrm{N}$, et al. Charac- teristics and survival of 750 children diagnosed with a renal tumor in the first seven months of life: a collaborative study by the SIOP/ GPOH/SFOP, NWTSG, and UKCCSG Wilms' tumor study groups. Pediatr Blood Cancer 2008;50:1130-4.

8. Hung N. Congenital "clear cell sarcoma of the kidney". Virchows Arch
2005;446:566-8.

9. Kural AR, Onal B, Ozkara H, Cakarir C, Ayan I, Agaoglu FY. Clear cell sarcoma of the kidney: a case report. BMC Urol 2006;6:11.

10. Rosso D, Ghignone GP, Bernardi D, et al. Clear cell sarcoma of the kidney with invasion of the inferior vena cava. Urol Int 2003;70:251-2.

11. Amin MB, Peralta-Venturina MN, Rossi JY, et al. Clear cell sarcoma of the kidney in an adolescent and in young adults. A report of four cases with ultrastructural, immunohistochemical and DNA flow cytometric analysis. Am J Surg Pathol 1999;23:1455-63.

12. Bhayani SB, Liapsis H, Kibel AS. Adult clear cell sarcoma of the kidney with atrial tumor thrombus. $J$ Urol 2001;165:896-7.

13. Oda H, Shiga J, Machinami R. Clear cell sarcoma of the kidney: two cases in adults. Cancer 1993;71:2286-91.

14. Mishra VK, Krishani N, Bandari M. Clear cell sarcoma of the kidney in an adult. Br J Urol 1993;72:118.

15. Toyoda Y, Yamashiota C, Sugimoto T, Yoshida M, Okada M. Clear cell sarcoma of the kidney with tumor extension into the right atrium. $J$ Cardiovasc Surg (Torino) 1998;39:48991.

16. Benchekroun A, Ghadouane M, Zannoud M, Alami M, Amhajji R, Faik M. Clear cell sarcoma of the kidney in an adult. Ann Urol (Paris) 2002;36:335.

17. Adnani A, Latib R, Bouklata S, Ajana A, Hammani L, Imani F. Sarcome à cellules claires du rein chez l'adulte: à propos d'un cas. J Radiol 2006;87:136-8.

18. Suzuki H, Honzumi M, Itoh Y, Umehara N, Moriyama S, FunadaM. Clear cell sarcoma of the kidney seen in a 3-day old newborn.Z Kinderchir 
1983;38:422-4.

19. Newbould MJ, Kelsey AM. Clear cell sarcoma of the kidney in a 4-month-old infant: a case report. Med Pediatr Oncol 1993;21:525-8.

20. Mazzoleni S, Vecchiato L, Alaggio R, Cecchetto G, Zorzi C, Carli M. Clear cell sarcoma of the kidney in a newborn. Med Pediatr Oncol 2003;41:153-5.

21. Wood DP, Kay R, Norris D. Renal sarcomas of childhood. Urology 1990;36:73-8.

22. Yumura-Yagi K, Inoue M, Wakabayashi $\mathrm{R}$, et al. Successful double autografts for patients with relapsed clear cell sarcoma of the kidney. Bone Marrow Transplant 1998;22:381-3.

23. Parikh SH, Chintagumpala M, Hicks J, et al. Clear cell sarcoma of the kidney: an unusual presentation and review of the literature. J Pediatr Hematol Oncol 1998;20:165-8.

24. Sharma SC, Menon PA. Clear cell sarcoma of the kidney. $J$ Postgrad Med 2001;47:206-7.

25. Kagan AR, Steckel RJ, Sleight G, Lock MM. Clear cell sarcoma of the kidney: a renal tumor of childhood that metastasize to bone. AJR 1986;146:646.

26. Balarezo FS, Joshi VV. Clear cell sarcoma of the pediatric kidney: detailed description and analysis of variant histologic patterns of a tumor with many faces. Adv Anat Pathol 2001;8:98-108.

27. Watts KE, Hansel DE, MacLennan GT. Clear cell sarcoma of the kidney. $J$ Urol 2011;185:279-80.

28. Boo YJ, Fisher JC, Haley MJ, Cowles RA, Kandel JJ, Yamashiro DJ. Vascular characterization of clear cell sarcoma of the kidney in a child: a case report and review. J Pediatr Surg 2009;44:2031-6.

29. Park DY KY, Chi JG. Intracranial metastasis from clear cell sarcoma of the kidney. JKMS 1997;12:473-76.

30. Bo Xie, Jiajun Ling.Clear cell sarcoma of the kidney-A case report. Chinese J Clin Onco. 2006; 2:151-152.

31. Murphy WM, Beckwith JB, Farrow GM.Tumors of the kidney. In: Murphy WM, editor. Tumors of the Kidney, Bladder and Related Urinary Structures. Washington D.C, The Armed Forces Institute of Pathology; 1993. p.67-81.

32. Sandstedt BE, Delemarre JF, Harms D, Tournade MF. Sarcomatous Wilms tumor with clear cells and hyalinization. A study of 38 tumors in children from the SIOP nephroblastoma file. Histopathology 1987;11:273-85.

33. Murphy WM, Beckwith JB, Farrow GM. Tumors of the kidney, bladder and related uriary structures. Washington D.C. The Armed Forces Institute of Pathology; 1993. p.67-81. 